\title{
Pioglitazon
}

\section{David Karásek}

III. interní klinika - nefrologická, revmatologická a endokrinologická, LF UP a FN Olomouc

Pioglitazon patří mezi léky, které primárně snižují inzulinovou rezistenci. V současné době je jediným dostupným inzulinovým senzitizérem. Kromě hypoglykemického působení má proto řadu dalších metabolicky příznivých účinků, které jsou zodpovědné za jeho pozitivní vliv na cévní stěnu. Sdělení obsahuje přehled kardiovaskulárních klinických hodnocení s pioglitazonem, jeho bezpečnostní profil a praktická doporučení pro jeho podávání.

Klíčová slova: pioglitazon, inzulinová rezistence, diabetes, kardiovaskulární onemocnění, srdeční selhání, karcinom močového měchýře.

\section{Pioglitazone}

Pioglitazone belongs to the drugs primarily reducing insulin resistance. Currently, it is the only insulin sensitizer available. In addition to hypoglycaemic action, it has a number of other metabolically beneficial effects that are responsible for its positive effect on the vascular wall. The paper provides an overview of cardiovascular clinical trials with pioglitazone, its safety profile and practical recommendations for its administration.

Key words: pioglitazone, insulin resistance, diabetes, cardiovascular disease, heart failure, bladder cancer.

\section{Úvod}

Diabetes mellitus (DM) 2. typu je spojen s řadou chronických komplikací, mezi nimiž dominují kardiovaskulární (KV) choroby, které jsou hlavní prríčinou zvýšené morality i morbidity diabetiků. Diabetici mají zhruba 2-4 násobně vyšší riziko aterosklerotických KV onemocnění (1, 2). Není tedy divu, že se do popředí léčby diabetu dostávají antidiabetika, která kromě snížení glykemie vedou také k úpravě dalších rizikových faktorů aterosklerózy a redukuji výskyt KV príhod. Jedním z takových léků je pioglitazon, jehož hlavním účinkem je pokles inzulinové rezistence (3). Patři do skupiny tzv. inzulinových senzitizérů, které působí prostřednictvím jaderných receptorů PPAR- $\gamma$ (peroxisome proliferator-activated receptor gamma). Inzulinová rezistence se komplexně podílí na patogenez diabetu 2. typu. Jejími prímými důsledky jsou hypertenze, diabetická dyslipidemie a hyperinzulinemie. Při dlouhodobém působení může vést kútlumu sekrece i syntézy inzulinu s následnou hyperglykemií. Inzulinová rezistence často několik let prèedchází vlastní manifestaci diabetu, a proto její včasné ovlivnění mưže mít význam nejen pro vývoj a kompenzaci diabetu, ale také pro vývoj jejich dalších projevů (3).

\section{Mechanismus účinku pioglitazonu (viz Obr. 1.)}

Pioglitazon vazbou na PPAR- $\gamma$ receptory aktivuje řadu genů, které příznivě ovlivňují metabolismus glukózy (oxidaci a transport glukózy, syntézu glykogenu), lipidů (dochází k poklesu plazmatických hladin volných mastných kyselin, snížení lipotoxicity) i činnost mitochondrií (3).

Hypoglykemický účinek pioglitazonu souvisí se snízením inzulinové rezistence v játrech, svalech i tukové tkáni. Dochází k poklesu glykemie na lačno (inhibice jaterní glukoneogeneze), postprandiálně (zvýšený uptake glukózy ve svalech) a snižuje se hladina volných mastných kyselin (klesá lipotoxicita). Ovlivněním lipotoxicity i prímým snízením inzulinové rezistence $v$ beta-buňkách pankreatu dochází ke zlepšení jejich funkce a zachování sekrece inzulinu (3).

Některé príiznivé účinky pioglitazonu jsou zřejmě zprostředkovány i částečnou aktivací PPAR-a receptorů, zejména jeho ovlivnění lipidového spektra. Na lipidový profil totiž nepůsobí pioglitazon a rosiglitazon („čistý” PPAR-y agonista) stejně. V prímém srovnání pioglitazon snižoval, zatímco rosiglitazon zvyšoval hladinu volných mastných kyselin a triglyceridů (TG) (4). Pioglitazon také vedl k vyššímu nárůstu HDL-cholesterolu (HDL-C) a k príiznivějšímu zastoupení LDL částic (došlo ke snížení malých denzních LDL a zvýšení počtu velkých méně aterogenních částic). Rosiglitazon celkovou koncentraci LDL-cholesterolu zvyšoval, pioglitazon ji naopak mírně snízil $(5,6)$. Pioglitazon tedy na rozdíl od rosiglitazonu pozitivně ovlivňuje i jednotlivé komponenty diabetické dyslipidemie.

Agonisté PPAR- $\gamma$ receptorů stimulují růst zralých adipocytů (vedou sice ke zvýšení hmotnosti, ale dochází k redistribuci tukové tkáně 
směrem od viscerálního k subkutánnímu tuku), mírně snižují krevní tlak a zlepšují funkci endotelu. Protizánětlivé účinky pioglitazonu jsou spojeny s poklesem hladin řady zánětlivých ukazatelů a mediátorů (C-reaktivního proteinu, matrixové metaloproteinázy-9, inhibitoru aktivátoru plazminogenu-1) a zvýšením produkce adiponektinu $(3,4)$. Pioglitazon také př́iznivě ovlivňuje vývoj a průběh nealkoholické jaterní steatózy (3). Snižuje albuminurii, působí ochranu podocytů renálních glomerulů a chrání také buňky hypoxického myokardu proti riziku reperfúzního poškození (4).

\section{Efekt pioglitazonu na metabolické parametry}

Několik randomizovaných klinických studií testujících monoterapii pioglitazonem vůči placebu u nemocných s diabetem 2. typu zjistilo (během 12-26 týdnů léčby) pokles glykovaného hemoglobinu $\left(\mathrm{HbA}_{1}\right)$ o 0,8-1,1 \% v závislosti na vstupním HbA 1 a dávce pioglitazonu (7). Recentní meta-analýza, která zahrnula 16 randomizovaných studií (asi 2600 jedinců), zjistila, že ve srovnání s ostatními antidiabetiky je pioglitazon v monoterapii stejně účinný jako deriváty sulfonylurey, inhibitory dipeptidyl-peptidázy 4 a o něco účinnější než metformin $\left(-0,12 \% \mathrm{HbA}_{1 c}\right)$ i akarbóza $\left(-0,68 \% \mathrm{HbA}_{1 c}\right)$ (8). Při srovnatelné efektivitě z hlediska vlivu na $\mathrm{HbA}_{1 c}$ byl pioglitazon účinnější v redukci glykemie na lačno (-0,24 mmol/l) a snižoval též signifikantně hladinu TG (-0,71 mmol/l). S jeho rostoucí dávkou se zvyšuje efekt na snížení HbA1c i glykemie $(3,8)$. Ze studie GLAL vyplývá, že po 2 letech jejího průběhu byl pioglitazon schopen udržet glykemickou kontrolu u většího počtu pacientů než gliklazid (9).

\section{Ovlivnění aterosklerózy a kardiovaskulárních př́hod}

Pozitivní vliv pioglitazonu na rizikové faktory a mediátory aterosklerózy (hyperglykemie, inzulinová rezistence, dyslipidemie, hypertenze, viscerální adipozita, chronický zánět, endotelová dysfunkce) vedl k předpokladu, že tento lék může príznivě ovlivnit aterosklerotický proces a snížit riziko KV prŕhod. Klinická hodnocení zjistila, že pioglitazon omezil narůst tlouštky intimy-medie společné karotidy $(10,11,12)$, navodil regresi koronární aterosklerózy $(12,13)$, snižil riziko restenózy koronárního stentu $(14,15)$ a také oddálil rozvoj ischemické choroby dolních končetin $(16,17)$. Tři větší studie zkoumaly efekt pioglitazonu na výskyt KV príhod.

Studie PROactive zahrnula 5238 diabetiků 2. typu v sekundární prevenci a hodnotila účinek pioglitazonu vưči placebu během asi tříletého sledování (18). Primární složený endpoint, který zahrnoval celkovou mortalitu, nefatální infarkt myokardu (IM), cévní mozkovou př́hodu (CMP), akutní koronární syndrom, revaskularizace koronárních a končetinových tepen a amputace nad kotníkem, sice nebyl signifikantně snížený (HR 0,90, p =0,095), nicméně hlavní sekundární endpoint zahrnující pouze celkovou mortalitu, nefatální IM a CMP, poklesl významně, a to o $16 \%$ (HR 0,84, p = 0,027). Subanalýza, která zahrnula jedince s predchozími IM nebo CMP, dokumentovala v této populaci 28\% redukci následného IM a 47\% redukci následné CMP (19).

Studie IRIS testovala hypotézu, zda léčba pioglitazonem sníži výskyt rekurentních KV príhod (IM a CMP) u inzulin-rezistentních jedinců bez
Obr. 1. Mechanismus účinku pioglitazonu

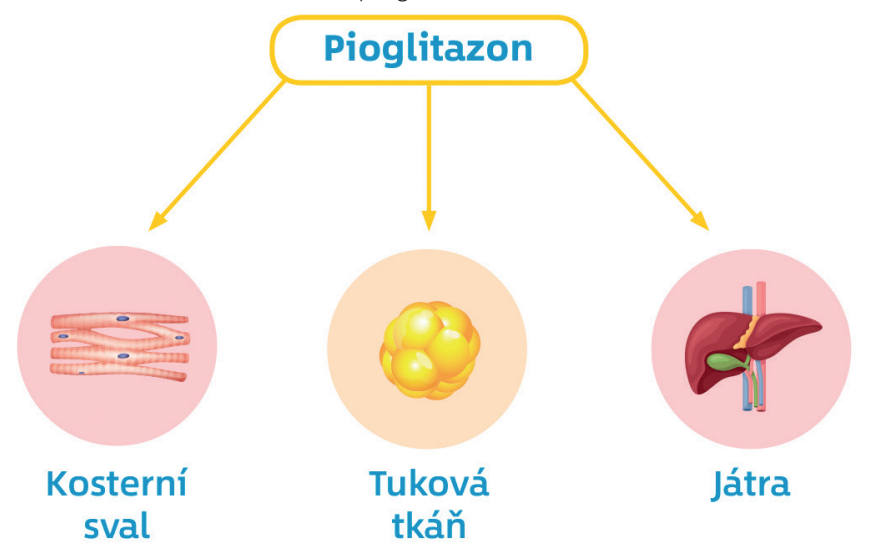

个Vychytávání glukózy

Adipogeneze

$\downarrow$ Glukoneogeneze

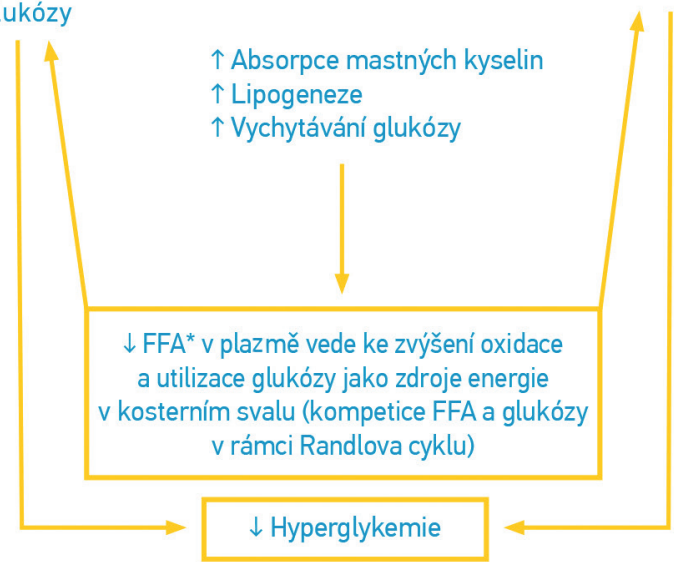

Prevzato a upraveno z publikace: Bailey CJ, Feher MD. Therapies for Diabetes: Including Oral Agents and Insulins. Birmingham UK: Sherborne Gibbs Limited 2004 (40)

diabetu s již prodělanou ischemickou CMP nebo tranzitorní ischemickou atakou (20). Randomizováno bylo 3876 pacientů, primárním sledovaným cílem byl vznik fatální nebo nefatální CMP, či IM. V léčené skupině došlo během pětiletého sledování k významné 24\% redukci primárního endpointu (HR 0,76, p=0,007) a signifikantní byl také méně častý vývoj diabetu (HR 0,48, p < 0,001). Následná meta-analýza do té doby publikovaných studiís pioglitazonem zjistila $26 \%$ redukci hlavních KV príhod na vrub této terapie (21).

Nedávno publikovaná italská studie TOSCA-IT zahrnula 3041 diabetiků 2. typu nedostatečně léčených metforminem, kteří byli randomizování k léčbě pioglitazonem, nebo derivátem sulfonylurey (22). Sledováni byli v průměru 5 let a během této doby nebyl mezi oběma skupinami zaznamenán signifikantní rozdíl ve výskytu primárního složeného cíle (celkové mortality, nefatálního IM, CMP, či urgentní koronární revaskularizace, $H R$ R 0,96, $p=0,79)$. Ve skupině léčené pioglitazonem byl zjištěn jen nižší výskyt periferních vaskulárních príhod. Nemocní měli menší výskyt hypoglykemických epizod. U pacientů léčených deriváty sulfonylurey byla významně vyšší potřeba přidání další antidiabetické medikace. Studie TOSCA-IT se lišila od výše uvedených studií (PROactive a IRIS) především tím, že se jí účastnili dominantně diabetici v primární prevenci (pouze 11 \% účastníků mělo anamnézu KV onemocnění) (3). Navíc průměrná dávka pioglitazonu byla pouze 23 mg denně. Mnohými je kritizovaná za některé metodologické limitace (nezaslepený design, velký počet předčasných ukončení studie, nízký počet KV príhod, nízká průměrná dávka 
INZERCE 
pioglitazonu atd.), a nelze tedy jednoznačně tvrdit, že jedinci v primární prevenci nemohou z léčby pioglitazonem také profitovat (3, 23).

I výsledky některých observačních studií podporují KV benefit pioglitazonu. Analýza dat více než 62000 diabetiků 2. typu z finských, švédských a britských registrů (European multidatabase cohort study) poukázala na nižší celkovou i KV mortalitu u skupiny nemocných léčených pioglitazonem (24). Data z UK-based General Practice Research Database (GPRD) od zhruba 27500 nemocných s diabetem doložila snížení celkové mortality i pokles hlavních KV příhod při kombinaci metforminu s pioglitazonem (25). A také další retrospektivní studie z britské databáze (Clinical Practice Research Datalink) zjistila u diabetiků léčených pioglitazonem signifikantní pokles výskytu CMP ve srovnání s pacienty léčenými jinými antidiabetiky (26).

\section{Bezpečnost léčby pioglitazonem}

Mezi nejčastější nežádoucí účinky pioglitazonu patří otoky, zvýšení tělesné hmotnosti, mírná anemie, poruchy zraku a hypestézie. Vzácně dochází ke zvýšení hladin jaterních enzymů a jaterní dysfunkci. Mezi nejzávažnější nežádoucí účinky patří kostní fraktury a retence tekutin s rizikem srdečního selhání. Diskutuje se také o možném riziku karcinomu močového měchýře (3).

Během léčby pioglitazonem dochází k průměrnému váhovému prírůstku 2-3 kg/rok, který je závislý na dávce léku. Paradoxně, čím vyšší je narůst hmotnosti, tím je větší pokles $\mathrm{HbA}_{1 c^{\prime}}$ nárůst sekrece inzulinu a inzulinové senzitivity (3). Pioglitazon vede k redistribuci tukové tkáně směrem k podkožnímu tuku, kde menší aktivní adipocyty akumulují volné mastné kyseliny namísto svalů, jater, cév a viscerálního tuku. Nárůst hmotnosti Ize minimalizovat používáním nižších dávek (do 30 mg/den), kombinací s metforminem, glifloziny, či s agonisty GLP-1 (glucagon like peptide-1) receptorů $(3,27)$.

Retence tekutin je dána periferní vazodilatací a retencí natria. Pioglitazon nemá negativní vliv na systolickou funkci levé komory a diastolickou dysfunkci může dokonce zlepšit (3). Nicméně u symptomatických jedinců může vést retence tekutin k dekompenzaci a klinické manifestaci srdečního selhání. Riziko otoků je závislé na dávce, zvyšuje jej simultánní léčba inzulinem a deriváty sulfonylurey, naopak se snižuje při současném podávání agonistů GLP-1 receptorů a gliflozinů, Ize jej nejlépe ovlivnit diuretiky působícími v distálním tubulu nefronů (spironolakton, amilorid, triamteren) $(3,27)$.

Thiazolidindiony působí negativně na skelet prostřednictvím aktivace PPAR-y receptorů, což v kostní dřeni navodí diferenciaci kmenové mesenchymální buňky směrem k adipocytu, místo k osteoblastu. To má za následek snížení kostní tvorby a zvýšení adipozity kostí, navíc dochází k aktivaci osteoklastů (28). Zvýšené riziko osteoporotických fraktur po pioglitazonu bylo prokázáno hlavně u postmenopauzálních žen, některé studie jej však zjistili i u mužů $(3,28)$. Tento negativní účinek zrejmě souvisí s délkou jeho podávání. Léčba pioglitazonem u postmenopauzálních žen se zjištěnou osteoporózou nebo u jedinců s již prítomnou osteoporotickou frakturou sice není absolutně kontraindikovaná, měli bychom však být s jeho podáváním obezřetní a zvážit, zda riziko nepřevýší očekávaný benefit léčby.

Ve studii PROactive bylo zaznamenáno nesignifikantní zvýšení počtu jedinců ( 16 vs. $6, p=0,069)$, kteří onemocněli karcinomem mo- čového měchýře (18). Proto si FDA vyžádala prospektivní studii, která měla zhodnotit možný kauzální vztah. Prospektivní desetileté klinické hodnocení 193099 nemocných s diabetem neprokázalo statisticky významné riziko karcinomu močového měchýře při léčbě pioglitazonem (29). Stejně tak nebylo toto riziko dokumentované ve studii IRIS (20), Či TOSCA-IT (22). A ani následné dlouhodobější sledování pacientů ze studie PROactive jej nepotvrdilo (30). Ke stejným výsledkům došly i některé meta-analýzy a retrospektivní studie (3, 8, 31, 32). Na druhou stranu několik meta-analýz, vycházejících zejména z observačních studií mírně zvýšené riziko karcinomu močového měchýře zjistilo, a to zejména v evropské populaci, při použití vyšších dávek a při dlouhodobém uživání pioglitazonu $(33,34,35)$. Toto riziko bylo významné při trvání léčby nad 3,6 roku a při dosažení kumulativní dávky nad 28000 mg pioglitazonu.

\section{Praktické poznámky k léčbě pioglitazonem}

Pioglitazon se po perorálním podání rychle vstřebává. Př́jem potravy neovlivňuje jeho vstřebávání, absolutní biologická dostupnost je vyšší než 80 \%. Má vysokou vazbu na plazmatické bílkoviny, výrazně se metabolizuje v játrech převážně prostřednictvím CYP2C8. Prưměrná hodnota poločasu eliminace nezměněného pioglitazonu je 5-6 hodin, jeho aktivních metabolitů 16-23 hodin. U člověka se vylučuje zejména stolicí (55 \%) a močí (45 \%). Klinicky významné interakce je možné očekávat při současné léčbě gemfibrozilem (inhibitor CYP2C8 - dochází k trojnásobnému zvýšení AUC pioglitazonu) a rifampicinem (induktor CYP2C8 - vede ke snížení AUC pioglitazonu o 54 \%) (36).

Hypoglykemický efekt nastupuje pozvolna, Ize jej očekávat za 6-8 týdnů, maximální účinek je pozorován za 3-6 měsíců (37). Léčbu Ize zahájit úvodní dávkou 15 mg nebo 30 mg jednou denně. Dávka může být postupně zvyšována až na 45 mg denně. U starších pacientů není úprava dávky nutná. Léčba by měla být zahájena co nejnižšími dávkami a dávkování zvyšováno postupně, zejména pokud je pioglitazon podáván v kombinaci s inzulinem $(36,37)$.

Pioglitazon je kontraindikován při přecitlivělosti na jednotlivé složky prípravku, u nemocných se srdečním selháním, s poruchou funkce jater, a také u jedinců s anamnézou diabetické ketoacidózy, rakoviny močového měchýře, či s anamnézou nevyšetřené makroskopické hematurie. Nesmí být podáván v období těhotenství a kojení (36). Před zahájením léčby by měly být vyšetřeny jaterní testy a dále sledovány v pravidelných intervalech. Léčba by neměla být zahájena u pacientů se zvýšenou hladinou jaterních enzymů nebo u pacientů s jakýmkoliv nálezem svědčícím pro jaterní onemocnění. U jedinců s mírnou a středně těžkou renální insuficiencí není nutná redukce dávky, u nemocných s těžkou renální insuficiencí je třeba postupovat opatrně. U dialyzovaných nejsou známy žádné údaje, proto by se pioglitazon neměl u těchto pacientů používat (36).

\section{Závĕr}

Pioglitazon představuje účinné antidiabetikum, které je schopné kromě glykemické kontroly také pozitivně ovlivnit KV riziko diabetiků, a to zejména u osob v sekundární prevenci. Jeho KV preventivní pưsobení je dáno př́znivými metabolickými, protizánětlivými a endotel-protektivními 
účinky, které souvisí s poklesem inzulinové rezistence. Pioglitazon navíc působí príznivě na vývoj nealkoholové jaterní steatózy/fibrózy, oddaluje přechod prediabetu do diabetu a zřejmě i pozitivně ovlivňuje diabetické onemocnění ledvin (3). Objevuji se také informace, které ukazují na jeho možnou roli v prevenci zhoršení kognitivních funkcí diabetiků $(38,39)$. Vhodným kandidátem pro léčbu pioglitazonem je nemocný, u něhož převládá podíl inzulinové rezistence na rozvoji hyperglykemie, a který má patrné také další projevy metabolického syndromu. Důležitým faktorem úspěšnosti léčby je jeho včasné podání (co nejdřive po metforminu).

Nežádoucí účinky pioglitazonu jsou předvídatelné a Ize je minimalizovat respektováním kontraindikací. Některým z nich se můžeme vyhnout pozvolnou titrací, optimálním dávkováním pioglitazonu a mo- nitorováním pacientů. Váhový prírůstek a retenci tekutin Ize př́iznivě ovlivnit simultánní léčbou některými dalšími antidiabetiky (metforminem, glifloziny, agonisty GLP-1 receptorů, jež navíc mohou přinést další pokles KV rizika), prípadně přidáním diuretika. V neposlední řadě je nutné zvážit i ekonomickou stránku léčby, která se nyní díky dostupnosti několika generických preparátů jeví, ve srovnání s novějšími antidiabetiky, jako poměrně výhodná. Do určité míry to koresponduje i s limitací preskripčního omezení pro předpis pioglitazonu z prostředků veřejného zdravotního pojištění, na rozdíl od některých ekonomicky náročnějších antidiabetik je možné léčbu zahájit i při $\mathrm{HbA}_{\mathrm{lc}}<60 \mathrm{mmol} / \mathrm{mol}$.

Podpořeno MZČR - RVO (FNOL, 00098892) a IGA_LF_2020_005.

\section{LITERATURA}

1. Emerging Risk Factors Collaboration, Sarwar N, Gao P, Seshasai SR, et al. Diabetes mellitus, fasting blood glucose concentration, and risk of vascular disease: a collaborative meta-analysis of 102 prospective studies. Lancet 2010; 375: 2215-2222.

2. Haffner SM, Lehto S, Rönnemaa T, et al. Mortality from coronary heart disease in subjects with type 2 diabetes and in nondiabetic subjects with and without prior myocardial infarction. N Engl J Med 1998; 339: 229-234.

3. DeFronzo RA, Inzucchi S, Abdul-Ghani M, Nissen SE. Pioglitazone: The forgotten, cost-effective cardioprotective drug for type 2 diabetes. Diab Vasc Dis Res 2019; 16: 133-143. 4. Goldberg RB, Kendall DM, Deeg MA, et al.; GLAI Study Investigators. A comparison of lipid and glycemic effects of pioglitazone and rosiglitazone in patients with type 2 diabetes and dyslipidemia. Diabetes Care 2005; 28: 1547-1554.

5. Deeg MA, Buse JB, Goldberg RB, et al.; GLAI Study Investigators. Pioglitazone and rosiglitazone have different effects on serum lipoprotein particle concentrations and sizes in patients with type 2 diabetes and dyslipidemia. Diabetes Care 2007; 30: 2458-2464.

6. Zou C, Hu H. Use of pioglitazone in the treatment of diabetes: effect on cardiovascular risk. Vasc Health Risk Manag 2013; 9: 429-433.

7. Sourij $\mathrm{H}$, Wascher TC. Pioglitazone in the management of Type 2 diabetes and beyond. Therapy 2007; 4: 517-533.

8. Alam F, Islam MA, Mohamed M, et al. Efficacy and Safety of Pioglitazone Monotherapy in Type 2 Diabetes Mellitus: A Systematic Review and Meta-Analysis of Randomised Controlled Trials. Sci Rep 2019; 9: 5389.

9. Tan MH, Baksi A, Krahulec B, et al.; GLAL Study Group. Comparison of pioglitazone and gliclazide in sustaining glycemic control over 2 years in patients with type 2 diabetes. Diabetes Care 2005; 28: 544-550.

10. Mazzone T, Meyer PM, Feinstein SB, et al. Effect of pioglitazone compared with glimepiride on carotid intima-media thickness in type 2 diabetes: a randomized trial. JAMA 2006; 296: 2572-2581.

11. Koshiyama H, Shimono D, Kuwamura N, et al. Rapid communication: inhibitory effect of pioglitazone on carotid arterial wall thickness in type 2 diabetes. J Clin Endocrinol Metab 2001; 86: 3452-3456.

12. Nissen SE, Nicholls SJ, Wolski K, et al. Comparison of pioglitazone vs glimepiride on progression of coronary atherosclerosis in patients with type 2 diabetes: the PERISCOPE randomized controlled trial. JAMA 2008; 299: 1561-1573.

13. Saremi A, Schwenke DC, Buchanan TA, et al. Pioglitazone slows progression of atherosclerosis in prediabetes independent of changes in cardiovascular risk factors. Arterioscler Thromb Vasc Biol 2013; 33: 393-399.

14. Nishio K, Sakurai M, Kusuyama T, et al. A randomized comparison of pioglitazone to inhibit restenosis after coronary stenting in patients with type 2 diabetes. Diabetes Care 2006: 29: 101-106.

15. Patel D, Walitt B, Lindsay J, Wilensky RL. Role of pioglitazone in the prevention of restenosis and need for revascularization after bare-metal stent implantation: a meta-analysis. J Am Coll Cardiol Intv 2011; 4: 353-360.

16. Althouse AD, Abbott JD, Sutton-Tyrrell K, et al. Favorable effects of insulin sensitizers pertinent to peripheral arterial disease in type 2 diabetes: results from the Bypass Angioplasty Revascularization Investigation 2 Diabetes (BARI 2D) trial. Diabetes Care 2013; 36: 3269-3275.

17. Dormandy JA, Betteridge DJ, Schernthaner G, et al. PROactive investigators. Impact of peripheral arterial disease in patients with diabetes — results from PROactive (PROactive 11). Atherosclerosis 2009; 202: 272-281.

18. Dormandy JA, Charbonnel B, Eckland DJ, et al. PROactive Investigators. Secondary prevention of macrovascular events in patients with type 2 diabetes in the PROactive Study (PROspective pioglitAzone Clinical Trial In macroVascular Events): a randomised controIled trial. Lancet 2005; 366: 1279-1289.

19. Wilcox R, Bousser MG, Betteridge DJ, et al. PROactive investigators. Effects of pioglitazone in patients with type 2 diabetes with or without previous stroke: results from PROactive (PROspective pioglitAzone Clinical Trial In macroVascular Events 04). Stroke 2007; 38: 865-873. 20. Kernan WN, Viscoli CM, Furie KL, et al. IRIS Trial Investigators. Pioglitazone after Ischemic Stroke or Transient Ischemic Attack. N Engl J Med 2016; 374: 1321-1331.

21. De Jong M, Vander Worp HB, Vander GraafY, et al. Pioglitazone and the secondary prevention of cardiovascular disease. A meta-analysis of randomized-controlled trials. Cardiovasc Diabetol 2017; 16: 134

22. Vaccaro O, Masulli M, Nicolucci A, et al. Effects on their incidence of cardiovascular events of the addition of pioglitazonem versus sulfonylureas in patients with type 2 diabetes inadequately controlled with metformin (TOSCA.IT): a randomised, multicentre trial. Lancet Diabetes Endocrinol 2017; 5: 887-897.

23. Abdul-Ghani M, Jayyous A, Asaad N, et al. Pioglitazone and cardiovascular risk in T2DM patients: is it good for all? Ann Transl Med 2018; 6:192.

24. Strongman H, Christopher S, Majak M, et al. Pioglitazone and cause-specific risk of mortality in patients with type 2 diabetes: extended analysis from a European multidatabase cohort study. BMJ Open Diabetes Res Care 2018; 6: e000481.

25. Morgan CL, Poole CD, Evans M, et al. What next after metformin? A retrospective evaluation of the outcome of second-line, glucose-lowering therapies in people with type 2 diabetes. J Clin Endocrinol Metab 2012; 97: 4605-4612.

26. Morgan CL, Inzucchi SE, Puelles J, et al. Impact of treatment with pioglitazone on stroke outcomes: A real-world database analysis. Diabetes Obes Metab 2018; 20: 2140-2147. 27. DeFronzo RA. Combination therapy with GLP-1 receptor agonist and SGLT2 inhibitor. Diabetes Obes Metab 2017; 19:1353-1362.

28. Karásek D. Vliv antidiabetické léčby na kost nemocných s DM 2. typu. Vnitř Lék 2016; 62: 582-587.

29. Lewis JD, Habel LA, Quesenberry CP, et al. Pioglitazone Use and Risk of Bladder Cancer and Other Common Cancers in Persons With Diabetes. JAMA 2015; 314: 265-277.

30. Erdmann E, Harding S, Lam H, et al. Ten-year observational follow-up of PROactive: a randomized cardiovascular outcomes trial evaluating pioglitazone in type 2 diabetes. Diabetes Obes Metab 2016; 18: 266-273.

31. Filipova E, Uzunova K, Kalinov K, Vekov T. Pioglitazone and the Risk of Bladder Cancer: A Meta-Analysis. Diabetes Ther 2017; 8: 705-726.

32. Korhonen P, Heintjes EM, Williams R, et al. Pioglitazone use and risk of bladder cancer in patients with type 2 diabetes: retrospective cohort study using datasets from four European countries. BMJ 2016; 354: i3903.

33. Tang $\mathrm{H}$, Shi W, Fu S, et al. Pioglitazone and bladder cancer risk: a systematic review and meta-analysis. Cancer Med 2018; 7: 1070-1080.

34. Adil M, Khan RA, Ghosh P, et al. Pioglitazone and risk of bladder cancer in type 2 diabetes mellitus patients: A systematic literature review and meta-analysis of observational studies using real-world data. Clin Epidemiol Glob Health 2018; 6: 61-68.

35. Qu H, Zheng Y, Wang Y, et al. Global and Regional Effects of Bladder Cancer Risk Associated with Pioglitazone Therapy in Patients with Diabetes. Sci Rep 2017; 7: 15804.

36. https://www.ema.europa.eu/en/documents/product-information/pioglitazone-accord-epar-product-information_cs.pdf

37. Pelikánová T, Bartoš $V$, a kol. Praktická diabetologie, 6. aktualizované a doplněné vydání. Praha: Maxdorf 2018.

38. Chou PS, Ho BL, Yang YH. Effects of pioglitazone on the incidence of dementia in patients with diabetes. J Diabetes Complications 2017; 31: 1053-1057.

39. Tseng CH. Pioglitazone Reduces Dementia Risk in Patients with Type 2 Diabetes Mellitus: A Retrospective Cohort Analysis. J Clin Med 2018; 7: 306.

40. Bailey CJ, Feher MD. Therapies for Diabetes: Including Oral Agents and Insulins. Birmingham UK: Sherborne Gibbs Limited 2004. 